\title{
The Effect of Cooperative Learning Methods on Social Skills for Students with Special Needs
}

\author{
Dewi Ratih Rapisa, Hayatun Thaibah \\ Faculty of Teacher Training and Education \\ Universitas Lambung Mangkurat \\ Banjarmasin, Indonesia \\ dratihrapisa.plb@ulm.ac.id, hayatun.thaibah.plb@ulm.ac.id
}

\begin{abstract}
Higher education is expected to help students to master social skills and to adapt to the surrounding environment. Students with special needs have the same rights to get treatment and interact with others. This study aims to determine whether cooperative learning method could improve social skills for students with special needs. This study used Quasi Experiment approach with One Group Pre and Posttest Design. This study use purposive sampling technique to choose relevant subject for the research. The subjects of this study were 8 students with special needs. The results of statistical calculation between the results of pretest and posttest obtained the value of $F=1.275$ shows significant influence on social skills between before and after treatment in the form of cooperative learning were given. Cooperative learning method can improve social skills of students with special needs at Special Needs Education Program of Lambung Mangkurat University, Banjarmasin.
\end{abstract}

Keywords-cooperative learning, Social Skills, Students with Special Needs.

\section{INTRODUCTION}

Humans as social beings are required to be able to overcome all the problems that arise as a result of interaction with the social environment and are able to present themselves in accordance with the rules or norms applied. Therefore, every individual is required to master social skills and adaptation to the surrounding environment.

Therefore, through the teaching and learning process carried out through a humane process that demands the involvement of children as individuals, the success of this process requires an attitude of life that is open to the environment and willing to cooperate with others [1]. Some personal and social problems that appear in elementary and secondary school students are individualistic attitudes, selfishness, indifference, lack of responsibility, laziness to communicate and interact. Low empathy is a phenomenon that shows the absence of social value everyday [2].

Social life skills as complex skills in positive behavior is justified by the others and do not do negative behaviors that are not approved by others [3]. Social life skill refers to the ability of individuals to organize the whole mind resulting in behavior consistent with the objectives of social interaction and can be received by the existing norms [3]. If social skills can be mastered, then the individual will be able to adjust to his social environment. Social skills can also be interpreted as the ability to behave socially and be acceptable to others [3]

Social skills as the ability of individuals to interpret and integrate and maintain behavior in various social contexts, so as to produce good social relationships and fun [4]. This included those who are able to interpret social interactions, participate in every change and were able to find a way out when faced with a conflict with a friend or social group. A child who has social skills if he shows the ability to organize his thoughts and feelings and can have the right behavior in all situations [5]. Therefore, children who experience failure in developing friendships are less sensitive to their own emotions will fail in interpersonal relationships and tend to experience social rejection [6]. The importance of social skills in individual life is evidenced by the correlation between these social skills and individual adaptability.

Life Skills Social includes skills in giving praise, complain because they do not agree on something, refuse the request of others, the ability to exchange experiences, demanding personal rights, giving advice to others, solving problems or conflicts, and dealing with other people who are older or have higher status [7]. There are several groups and organizations in the community that play an important role in socialization. Behavior that is owned by children is realized or not, influenced by peers, family environment, lecturers at school, forms of games and learning models in each school. This is in accordance with the opinion which states that there are several factors that influence children's social development, namely children's social groups, imitation of behavior and participation in social groups [8].

Identification results social skills with several aspects, namely interpersonal behavior, behavior related to oneself, behavior related to academic success, peer acceptance, and communication skills [9]. According to one researcher in his research focused on five social skills namely cooperation, assertiveness/initiative, responsibility, empathy and selfcontrol [10]

Per high teacher is a continuation of secondary education which is organized to prepare students to become members of the community who have academic and professional abilities can apply, develop and create science, technology and art (Law 2 of 1989, article 16, paragraph (1)). 
Higher education is education at a higher level than secondary education in the path of school education (PP 30 of 1990, article 1 paragraph 1).

Actually, competition is not the only learning method that can and must be used. There are three choices of methods, namely competition, individual, and cooperative learning [11]. Research will use cooperative learning in the learning process, because it is measured here is not achievement but a social skills of student through the learning process. Cooperative learning itself is a learning process which is learning mutual cooperation or carried out in groups, because this process is different from careless group learning. There are basic elements in cooperative learning methods that differentiate them from group divisions which are carried out carelessly namely positive interdependence, personal responsibility, face to face, communication between members, and evaluation in group processes [11].

Cooperative Learning is a broader concept encompassing all types of group work including forms that are more led by lecturers or directed by lecturers .In general, cooperative learning is considered more directed by the Lecturer, where the Lecturer assigns assignments and questions and provides materials and information designed to help students solve problems [34].

Cooperative Learning is a learning model that prioritizes groups. Every student in the group has a different level of ability (high, medium, low) and if possible group members come from different races, cultures, tribes and pay attention to gender equality. Cooperative learning model prioritizes cooperation in solving problems to apply knowledge and skills in order to achieve learning objectives [12].

In cooperative learning students learn together in small groups that help each other. Classes are arranged in groups of 4-6 students , with heterogeneous abilities [13]. Heterogeneous intent is composed of a mixture of student abilities, gender and ethnicity. This is useful to train students to accept differences and work with friends who have different backgrounds.

The purpose of cooperative learning is different from conventional groups that implement a competition system, where individual success is oriented towards the failure of others. The purpose of cooperative learning is to create a situation where individual success is determined or influenced by the success of the group [14]. Cooperative learning models are developed to achieve at least three important learning goals, namely [15]: academic learning outcome, the acceptance of individual differences and the development of social skills.

Research that has been conducted shows that cooperative learning techniques can facilitate students' learning and improve academic achievement, increase student memory, enhance the increase of student satisfaction with learning experience, help students develop oral communication skills, develop social skills of students, and promote themselves to help promote positive relations between races [16].

The efect of cooperative learning is not only seen in cognitive and psychomotor aspects. For the content which has affective nature, students can practice to respect the opinions and existence of friends, selfishness and domination of "smart" students in the group begin to diminish. The students who have ordinary abilities get a more appreciated place, because it is in accordance with the capacity that can contribute to the group, so this way can increase their confidence [17]. So, in the group, all members, no matter how small their contribution is, deserve to be appreciated, and not just smart students .

A number of cooperative learning structures used in teaching and learning activities include jigsaw, think-pairshare, step-three interviews, Round Robin Brainstroming , three minute reviews, Numbered Heads Together, Solo Couple Teams, Circle the Sage, and Partners [16]. There are five approaches to cooperative learning, namely: STAD (Student Teams Achievement Division), Jigsaw, Two Stay Two Stray, Group Investigation and Structural Approach [18].

Lecturers gave awards to groups by awarding scores; based on the acquisition of the scores individual learning outcomes was increasing from the base score to the next quiz score. Material should naturally be divided into parts of learning material. It should be noted that if using jigsaw to learn new material, it is necessary to prepare a coherent and sufficient guidance and material content so that the learning objectives can be achieved [11]. This Jigsaw technique can improve social skills in the aspects of academic success and communication skills.

Cooperative learning model is one of the learning models that support contextual learning which includes five main elements, namely: positive interdependence; individual responsibility; personal interaction; expertise in collaboration, and group processes [14]. The thought is that social skills can be developed using cooperative learning methods in the learning process. Not apart from the objectives to be studied, that is, to improve social skills for students with special needs by using cooperative learning methods; then this problem can be formulated that cooperative learning methods can improve social skills for students with special needs. This study aims to determine whether cooperative learning methods can improve social skills for students with special needs.

\section{METHOD}

This study aims to determine whether cooperative learning methods can improve social skills for students with special needs. This study uses the Quasi Experiment approach, which is an approach that is done with the aim to determine the influence of cooperative learning variables and social skills of students with special needs by comparing the scores obtained by the subject before and after being given treatment. This study use purposive sampling technique to choose relevant subject for the research. The subjects were 8 students with special needs. The experiment used a re-experiment with experimental design was One Group Pre and Posttest Design . Instrument in this research is the social skill scale. The subjects were 8 students with special needs. The measuring instrument used in this study is a social skill scale [9], namely interpersonal behavior, self-related behavior, behavior related 
to academic success, peer acceptance, and communication skills. The data analysis used in this study was a linear regression analysis with the help of the Computer Statistical for Social Science Program (SPSS).

\section{RESULT AND DISCUSSION}

Following the results of students' social skills through the implementation of cooperative learning, can be seen in Figures $1,2,3,4$ and 5 .

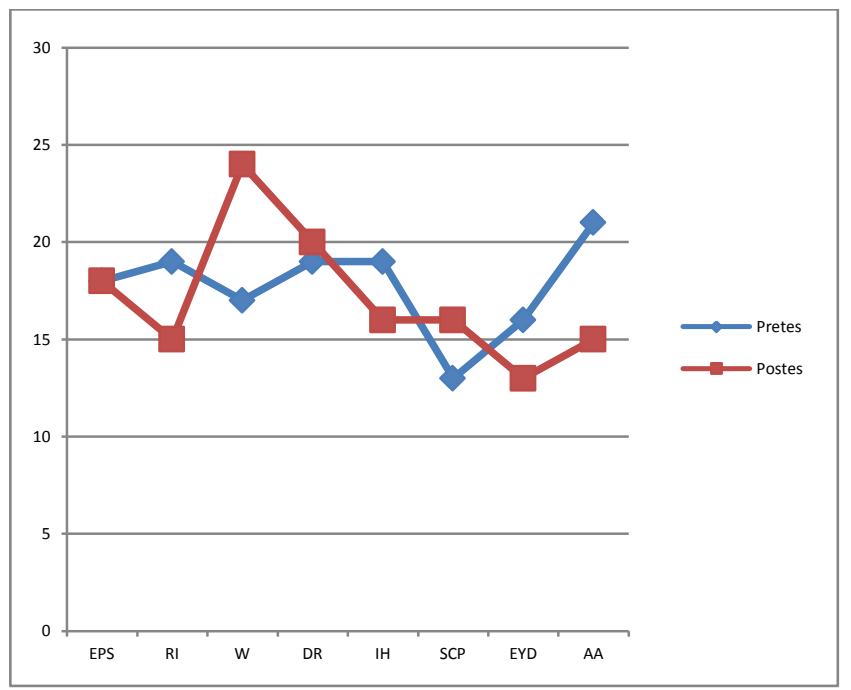

Fig. 1. Interpersonal Aspects

Figure 1. show that ha sil above research found there is some students with special needs who experienced a decrease after being given treatment in the form of cooperative learning in interpersonal aspects namely RI, IH, SCP, EYD and AA.

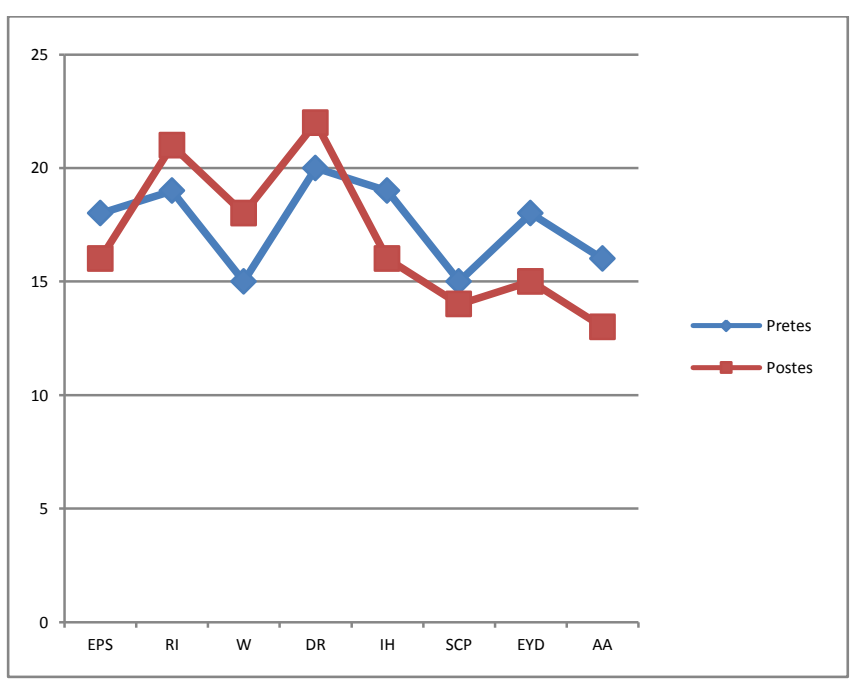

Fig. 2. Aspects of Behavior with Yourself

Figure 2. showed that the results of the above research found that there were some students with special needs who experienced a decrease after being given treatment in the form of cooperative learning in behavioral aspects with themselves namely EPS, IH, SCP, EYD and AA.

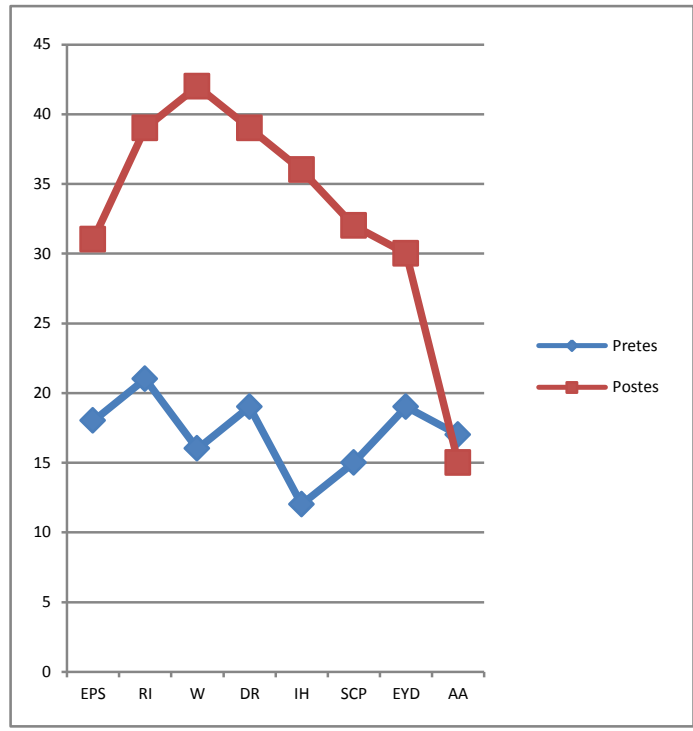

Fig 3. Academic Succes

Figure 3 shows that the results of the above study found that there were some students with special needs in the Extraordinary Education Study Program of Lambung Mangkurat University which experienced a decrease after being given a form of cooperative learning in the aspect of academic success, namely AA.

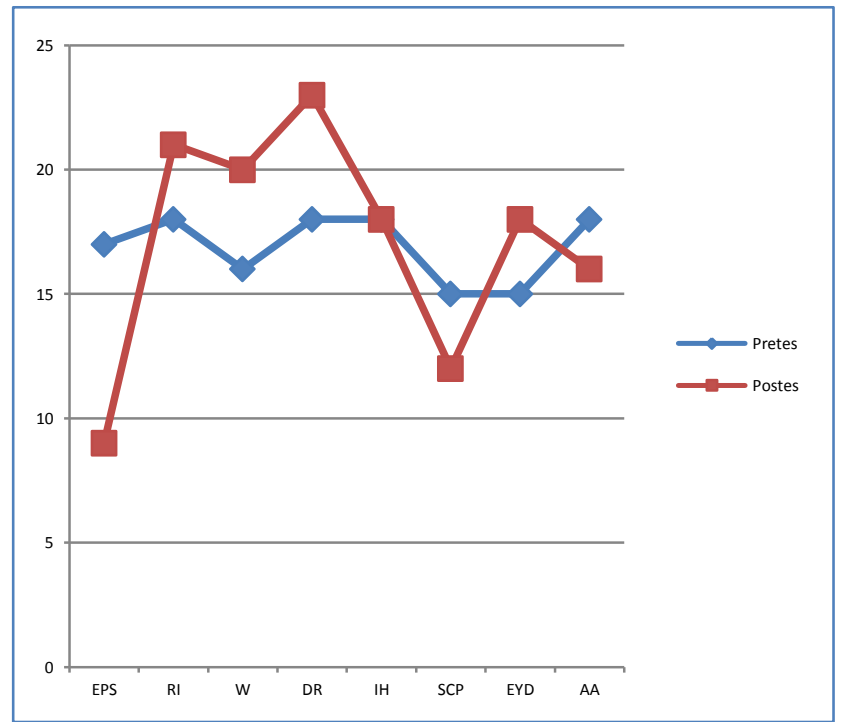

Fig. 4. Aspects of Accepting Peer Friends

Figure 4 shows that the results of the above study found that there were some students with special needs which experienced a decrease after being given treatment in the form 
of cooperative learning in aspects of peer acceptance namely EPS, SCP and AA.

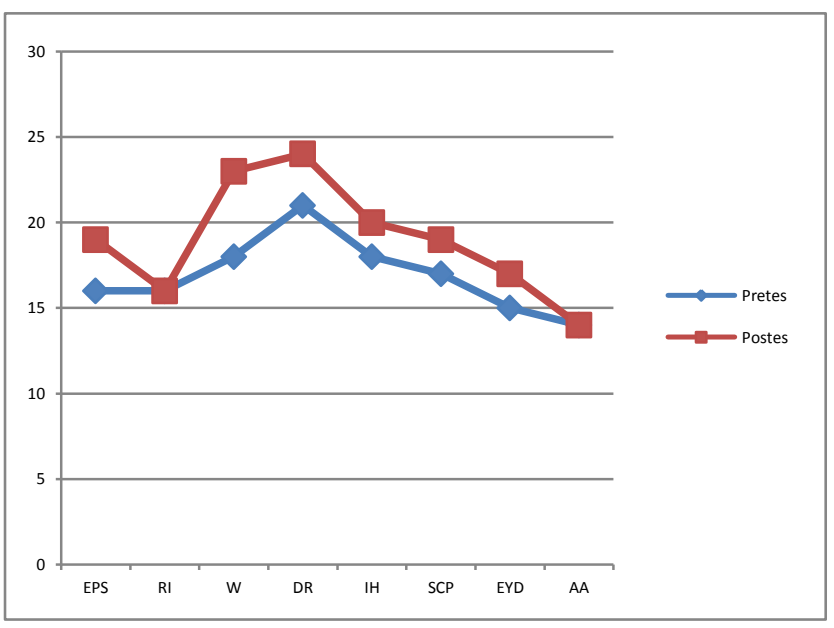

Fig. 5. Aspects of Communication Skills

Figure 5 shows that the above results do not exist decreased after treatment given in the form of cooperative learning skill, with communication aspect on students with special needs in Special Education Program Mangkurat University.

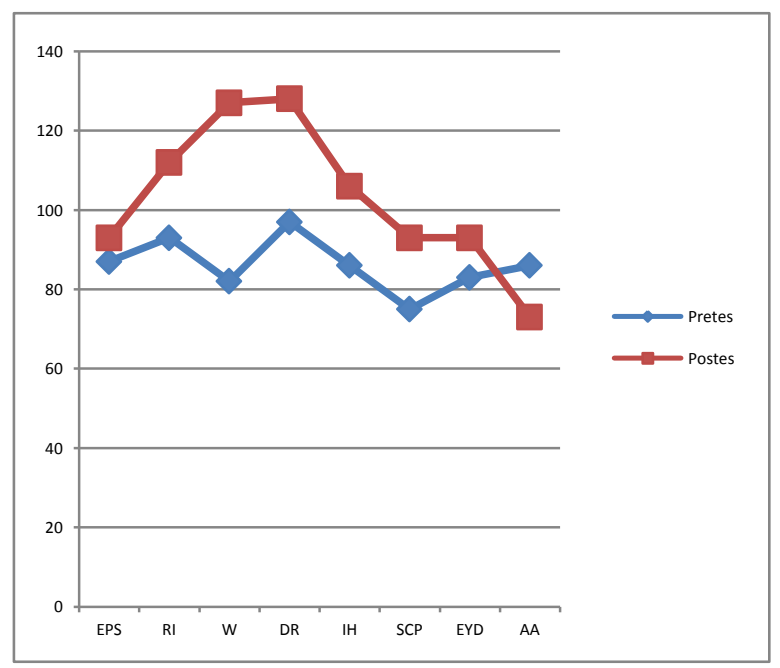

Fig. 6. Social Skills Results

The results of the above study found that AA subjects experienced a decrease in treatment given a form of cooperative learning to improve social skills. The training on aspects of interpersonal behavior, self-behavior, academic success and peer acceptance. While aspects of communication are balanced.

The results of research conducted on students with special needs using statistical calculations between the results of the pretest and posttest obtained indigo i $\mathrm{F}=1.275$ shows the influence on significant social skills between before and after being given treatment in the form of cooperative learning .
Social skills after treatment are higher than before treatment (X pre $=86,13$ becomes $\quad$ X post $=103.13$ ).

Chart comparison of the pretest, and posttest on skills so unlucky can be seen in Figure 7 :

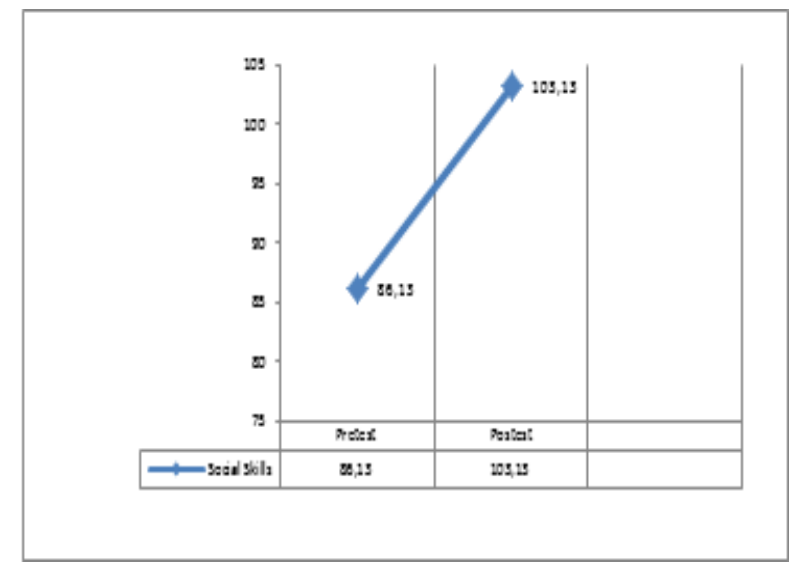

Fig. 7. Comparison of Social Skills between Pretest and Posttest.

Based on Figure 7 above it is known that social skills in students with special needs at the University of Lambung Mangkurat at the pretest and posttest showed that social skills at the time of posttest experienced a significant increase compared to the pretest. The change in mean of social skills in a row was pretest of 86,13 to 103.13 at posttest .

The results show that the hypothesis accepted. There is the influence of social skills of students with special needs of the Special Needs Education Program of Lambung Mangkurat University, Banjarmasin before and after being given treatment in the form of cooperative learning methods, it's means that cooperative learning methods can improve the social skills of students with special needs of the Special Needs Education Program of Lambung Mangkurat University, Banjarmasin after being given a cooperative method learning higher than skill social before cooperative learning methods are carried out.

The results obtained are in accordance with the theory put forward by previous researchers that social skills are very important factors in child development [19]. One form of socialization in universities is the ability of students to interact with friends, lecturers and those around them. Finally the experience of students with peers will have an influence on attitudes when studying in college to be accepted in their social environment and can also accept their social environment, individuals must strive to develop social skills, namely the ability to interact with the social environment.

The developmental tasks of adolescence according to previous research, as follows accept the reality of the physical changes they experienced and can perform roles according to their type effectively and feel satisfied with the situation; learning has a social role with peers, both similar friends and opposite sex in accordance with their respective sexes; achieve freedom from dependence on parents and other adults; develop intellectual skills and concepts about community life; 
looking for guarantees that one day they must be able to stand alone in the economic field in order to achieve economic freedom, prepare themselves to determine a job that suits their talents and abilities, understand and be able to behave that can be accounted for in accordance with the norms and values that apply; obtain information about marriage and prepare themselves to have a family and get an assessment that able to behave according to scientific views.

The study also found that there is one aspect which is part of $t$ social skills componen in students with special needs namely aspects of communication skills . Aspects of communication skills is one of the skills needed to establish a good social relations, the child's ability to communicate can be seen in the form of using a low voice when speaking, say hello to friends when they met, dared to ask, and dare to say if want to borrow items with friends .

However, the other aspects did not increase by using cooperative learning methods, namely interpersonal aspects, self-related aspects of behavior, academic success and peer acceptance. Therefore, students with special needs of the Special Education Study Program at Lambung Mangkurat University in Banjarmasin need further guidance to improve their social skills. Needs for this social skill is also very important in primary school age children because at this time it is a time to develop personalities such as to be loved and actualize themselves, cooperative method influences or can improve students' social skills. That's why important to every student learning through cooperative method [20], [9].

So, cooperative learning method is a good teaching and learning method to improve the social skills of students with special needs of the Special Needs Education Program of Lambung Mangkurat University in Banjarmasin who have difficulties in communication skills. The research that has been carried out has the disadvantage of a less long time in research and data collection in the form of observation data, so that in this study there is no comparison between scale data and observation data. In addition to these weaknesses, research also has advantages, lecturers get a new method in the learning process.

\section{CONCLUSION}

The results of research and discussion can be concluded that cooperative learning methods can improve social skills in students with special needs of Special Needs Education Program of Lambung Mangkurat University in Banjarmasin .

\section{REFERENCES}

[1] J. Drost, From KBK to SBM Educational Essays. Jakarta: Kompas book, 2005.

[2] E. Syaodih, "Development of Cooperative Learning Models to Improve Social Skills," Educ. J. Educ. Cult., 2009.

[3] N. Frederickson and C. T., Special Educational Needs, inclusion and Diversity a textbook. Buchingham Philadelphia: Open University Press, 2002.

[4] S. S. Goldstein and M. Susan, Understanding and Managing Childrean's Classroom Behavior: Building Social Skill in the Classroom. Canada: John Wiley \& Sons, 1995.

[5] P. Erwin, Friendship and Peer Relations in Children. England: John Wiley \& Sons Ltd, 1993.

[6] D. . Cragar and L. S. Horvarth, "The Application of Social Skills Training in the Treatment of a Child with Asperger's Disorder," Clin. Case Study, vol. 2, pp. 34-49, 2003.

[7] R. J. Syamril and I. K. Nuryana, "Effect of Emotional Intelligence Training on Students' Social Skills with Special Needs," J. Gift. Creat., vol. 2, no. 1, pp. 13-19, 2008.

[8] M. Kibtiyah, "The effectiveness of games is cooperative in improving the social skills of kindergarten children," Thesis . Faculty of Psychology, University of Gajah Mada (Unpublished, 1999.

[9] K. L. Elksnin and N. Elksnin, Assessment \& Instructions of Social Skills. San Diego: Singular Publishing Group, Inc, 1995.

[10] E. Backe-Hansen and T. Odgen, "Competent Girls and Problematic Boys?Differences in Two Cohorts of Norwegian 10 - and-13 Years Olds," Childhood, vol. 3, no. 3, pp. 331-350, 1996.

[11] A. Lie, "Cooperative Learning." PT. Gramedia Widya Indonesian facilities, Jakarta, 2004.

[12] A. Suprijono, Cooperative Learning, PAIKEM Theory \& Application. Yogyakarta: Student Library Publisher, 2009.

[13] Y. Yusuf, "Biology Learning Process \& Results through Cooperative Learning (Jigsaw).” 2003.

[14] R. E. Slavin, Educational Psychology: Theory and Practice (4 th ed). Boston: Allyn \& Bacon, 1994

[15] M. Ibrahim, F. Rachmadiarti, M. Nur, and I. Ismono, Cooperative Learning. Surabaya: UNESA Press University, 2000.

[16] S. Kagan, Cooperative Learning Resources for Teachers. San Juan Capistrano, CA: Resources for Teachers, 1992.

[17] S. Mardiana, "Cooperative Learning Empowers Students." http: // www.mbeproject.net/mbe1314.html, 2007.

[18] R. Arends, Learning to teach. New York: McGraw-Hill Higher Education, 2004.

[19] S. Evans, "Acceleration a Legitimate Means of Meeting the Needs of Gifted Children.” http://www.nexus.edu.au/TeachStud/gat/evanss.htm, 1996.

[20] G. A. Davis and S. B. Rimm, Teaching The Gifted and Talented Children. Boston: Allyn \& Bacon, 1998 